Check for updates

Cite this: Anal. Methods, 2018, 10, 646

\title{
A high-throughput method for orthophosphate determination of thermostable membrane-bound pyrophosphatase activity
}

\begin{abstract}
Keni Vidilaseris, (iD a Juho Kellosalo ${ }^{b}$ and Adrian Goldman (iD *ac
Membrane-bound pyrophosphatases (mPPases) are homodimeric integral membrane proteins that hydrolyse pyrophosphate into orthophosphates coupled to the active transport of protons or sodium ions across membranes. They occur in bacteria, archaea, plants, and protist parasites. As they are essential in protist parasites and there are no homologous proteins in animals and humans, these enzymes represent an excellent drug target for treating protistal diseases. Experimental screening to find drug candidates is an important step to discover new hit compounds. For that, a cheap, simple, and robust assay is needed. Here we report the application of the molybdenum blue reaction method for a medium throughput microplate activity assay of the hyperthermophilic bacterium Thermotoga maritima mPPase and the possible application of the assay to screen inhibitors of membrane-bound pyrophosphatases.
\end{abstract}

Received 31st October 2017

DOI: $10.1039 / c 7 a y 02558 \mathrm{k}$

rsc.li/methods

magnesium. In these parasites, mPPases are important for maintaining the acidity of the acidocalcisome and its functions for osmoregulation upon passage of the parasite from the insect vector to the mammalian host. ${ }^{\mathbf{1 4}}$ It has been shown that knocking out mPPase expression in $T$. gondii produced parasite cells more sensitive to extracellular environments that make them avirulent in mice. ${ }^{15}$

As they are essential in protist parasites and because they have no homologous proteins in multicellular organisms, mPPases may be an excellent potential drug target for protistal diseases. ${ }^{16}$ For that, a simple, cheap, and sensitive method to determine the reaction product of mPPases is needed to screen drug candidates. Several methods have been reported for determining the phosphate released from the enzymatic reaction of pyrophosphatase, including colourimetric, ${ }^{17-21}$ fluorometric, ${ }^{22,23}$ enzymatic, ${ }^{24-26}$ and radiolabeling ${ }^{27}$ methods. Each method has its drawbacks and advantages. The colourimetric method based on the molybdenum blue reaction, first developed by Fiske and Subbarow, ${ }^{17}$ is the most commonly used. This method involves the formation of 12-phosphomolybdic acid (PMA) from orthophosphate and molybdate under acid conditions, which is then reduced to a dark blue colour of phosphomolybdenum species. ${ }^{28}$ Here we explore the use of the colourimetric molybdenum blue method for medium to high throughput analysis of the activity of the hyperthermophilic bacterium T. maritima mPPase (TmPPase) as a model system.

TmPPase is a sodium pumping mPPase and has maximum activity in the presence of millimolar concentrations of sodium and potassium ions at $71^{\circ} \mathrm{C}^{.29,30}$ The structures of TmPPase and the $\mathrm{H}^{+}$-pump mPPase from mung bean (Vigna radiata) (VrPPase) $)^{31,32}$ are very similar and show complete conservation 
of the position and identity of all the catalytic residues. Protist mPPases are $\mathrm{H}^{+}$-pumps, like VrPPase, and therefore have conserved residues in the catalytic region too. The available structures can be used for structure-based drug design experiments and for experimental screening of compounds.

\section{Experimental}

\section{Chemicals}

Hydrochloric acid ( $\mathrm{HCl}$ ), soybean lecithin, ascorbic acid, sodium chloride, imidodiphosphate (IDP), calcium chloride, sodium fluoride, sodium phosphate dibasic $\left(\mathrm{P}_{\mathrm{i}}\right)$ and sodium pyrophosphate $\left(\mathrm{Na}_{2} \mathrm{PP}_{\mathrm{i}}\right)$ were purchased from Sigma. Ammonium heptamolybdate tetrahydrate, sodium meta-arsenite, acetic acid, potassium chloride, dimethyl sulfoxide (DMSO), ethanol and magnesium chloride were purchased from Merck. Trisodium citrate dehydrate was purchased from Fluka and dodecyl maltoside (DDM) was purchased from Melford.

\section{Reagent preparation}

Solution A + B. Solution A was made by dissolving $0.3 \mathrm{~g}$ of ascorbic acid into $10 \mathrm{~mL}$ of cold $0.5 \mathrm{M} \mathrm{HCl}$ and solution B was made by dissolving $70 \mathrm{mg}$ of ammonium heptamolybdate in cold milli-Q water. Both solutions were kept on ice for at least $30 \mathrm{~min}$ before using. Before the assay, both solutions were mixed to generate solution $\mathrm{A}+\mathrm{B}$, which has a yellow colour. This solution was kept on ice and was stable for 3 hours.

Arsenite-citrate solution. $5 \mathrm{~g}$ of sodium arsenite and $5 \mathrm{~g}$ of trisodium citrate dihydrate were dissolved in $100 \mathrm{~mL}$ of milli-Q water. Then, $5 \mathrm{~mL}$ of iced-acetic acid was added to the solution and filled up to $250 \mathrm{~mL}$ with milli-Q water. The solution is stable for over a year stored at room temperature in the dark.

Protein reactivation. TmPPase expression and purification are described elsewhere. ${ }^{30}$ For protein reactivation, $40 \mu \mathrm{L}$ of $30 \mathrm{mg} \mathrm{mL}^{-1}$ liposome (soybean lecithin) was mixed with $22.5 \mu \mathrm{L}$ $20 \%$ dodecyl maltoside (DDM) (Melford) and incubated at $55^{\circ} \mathrm{C}$ for 15 minutes. After the protein solution had cooled to RT, 36.5 $\mu \mathrm{L}$ of reactivation buffer (20 mM MES pH 6.5, 3.5\% glycerol, $0.05 \%$ DDM, 2 mM DTT) was added. Finally, one microliter of $13 \mathrm{mg} \mathrm{mL} \mathrm{m}^{-1}$ of pure protein sample was added to the solution and mixed.

\section{Assay}

The protocol is illustrated in Fig. 1. $40 \mu \mathrm{L}$ reaction mixture per well containing $75 \mathrm{mM}$ Tris- $\mathrm{HCl} \mathrm{pH} 8.0,3 \mathrm{mM} \mathrm{MgCl}_{2}, 125 \mathrm{mM}$ $\mathrm{KCl}, 25 \mathrm{mM} \mathrm{NaCl}$, and $0.2 \mu \mathrm{L}$ of reactivated $\mathrm{TmPPase}^{30}$ were added to PCR tube strips (8 tubes for each strip) using a multichannel pipette and sealed with an adhesive sealing sheet (Thermo Scientific). Then, the sealing sheet was cut to separate each strip. The samples were then preincubated for 5 minutes at $71{ }^{\circ} \mathrm{C}$ on a 96-well heating block with a 20 second interval between each strip for ease of performing the subsequent steps. After incubation, $10 \mu \mathrm{L}$ of $2 \mathrm{mM}$ sodium pyrophosphate was added to each tube, mixed, and incubated for 1-10 minutes. The reaction was stopped by putting each strip on the cooling apparatus for 10 minutes. The cooling apparatus was made by placing a 96-well PCR plate (Bio-Rad) on a polystyrene Petri dish (size $150 \mathrm{~mm} \times 15 \mathrm{~mm}$ ) (Sigma) filled with water and then frozen for $1 \mathrm{~h}$. After 5 minutes of cooling, strips were centrifuged briefly to collect the condensed moisture below the sealing sheet, put back onto the cooling apparatus, and the sealing sheets were removed. After 10 minutes of cooling, $60 \mu \mathrm{L}$ of solution $\mathrm{A}+\mathrm{B}$ was added to each tube and they were then incubated for 10 minutes. Finally, $90 \mu \mathrm{L}$ of sodium arsenite solution was added, incubated at room temperature for at least 30 minutes to reach stable colour production, and then transferred into the clear PS microplate 96 wells (Thermo Scientific) with a multichannel pipette. The absorbance was measured at $860 \mathrm{~nm}$ using Multiskan Go (Thermo Scientific). For standard calibration, $50 \mu \mathrm{L}$ of reaction mixtures containing $0-800 \mu \mathrm{M}$ of $P_{i}$ were tested. A reaction mixture with no $P_{i}$ added was used as a blank. All measurements were done in triplicate. Analysis and regression were performed with Prism 6 software (GraphPad Software, San Diego, CA).

\section{Results and discussion}

\section{Method development}

In drug development projects, experimental screening is an important step to discover new hit compounds. For that, a cheap, simple, and robust assay is needed. Here we explore the viability of a colourimetric method based on the molybdenum blue reaction for a medium throughput assay to determine the activity of TmPPase. We adapted the existing protocol ${ }^{\mathbf{3 0 , 3 3}}$ for mPPase activity assays to a 96 well format using twelve PCR tubes strips (Fig. 1). We chose the molybdenum blue assay of Baginski et al. ${ }^{34}$ over a similar assay from Heinonen and Lahti ${ }^{20}$ and the malachite-green assay ${ }^{\mathbf{2 1}}$ because it is 2 -fold more sensitive than the former and, unlike the latter, it does not show interference in the presence of high concentrations of phospholipid (data not shown), which we need for the activity of our enzyme (see below). Thus, even though the malachite green assay would be 10 -fold more sensitive ${ }^{21}$ than the Baginski assay $^{34}$ it is impractical for our purposes.

The reaction volume for each tube is $50 \mu \mathrm{L}$, which consists of $40 \mu \mathrm{L}$ of reaction buffer containing enzyme and $10 \mu \mathrm{L}$ of substrate $\left(\mathrm{PP}_{\mathrm{i}}\right)$. We used the optimal temperature of TmPPase activity $\left(71^{\circ} \mathrm{C}\right)^{30}$ for the reaction condition in a 96 well heating block. During initial testing, loss of solution because of evaporation led to poorly reproducible results. Sealing the tubes with capping strips did not help due to the difficulty in the closing and opening the caps during the assay, which leads to delays in the timing. We solved this problem by using an adhesive sealing sheet which we cut to fit the tube strips. With this sealing, we can rapidly open and close the tube strips during the assay. In the assay, $40 \mu \mathrm{L}$ of reaction mixtures (reactivated enzyme in the reaction buffer) were incubated in the heating block for 5 minutes to raise the temperature of the reaction mixture to $71{ }^{\circ} \mathrm{C}$. After the addition of $10 \mu \mathrm{L}$ of $\mathrm{PP}_{\mathrm{i}}$, the reaction mixture was incubated at $71{ }^{\circ} \mathrm{C}$ for 1-10 minutes for the enzymatic reaction. The reaction was stopped by putting the strip tubes onto the 96-well cooling apparatus for 10 minutes. During this time, strips were spun down briefly to collect the any water 


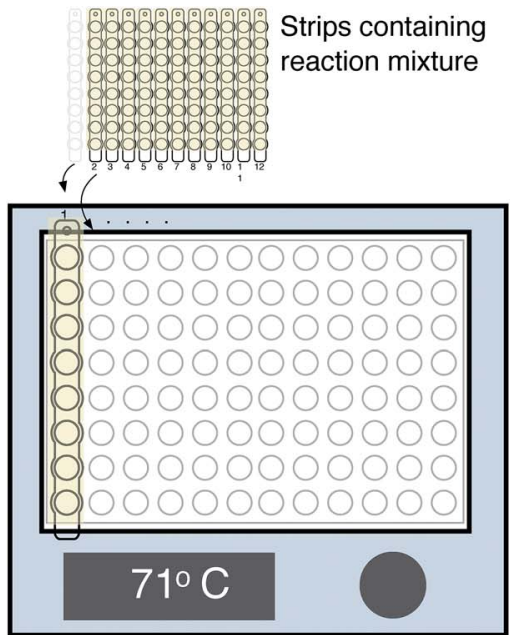

Incubation for 5 min with $20 \mathrm{~s}$ interval between each strip.

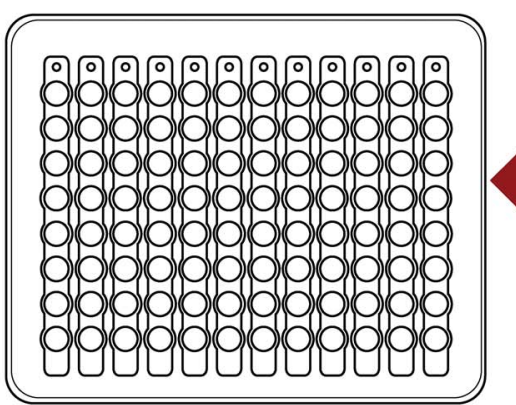

Further cooling for $10 \mathrm{~min}$, then addition of arsenic solution.

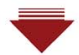

Incubation for 30 min (RT), Measure absorbance $860 \mathrm{~nm}$.
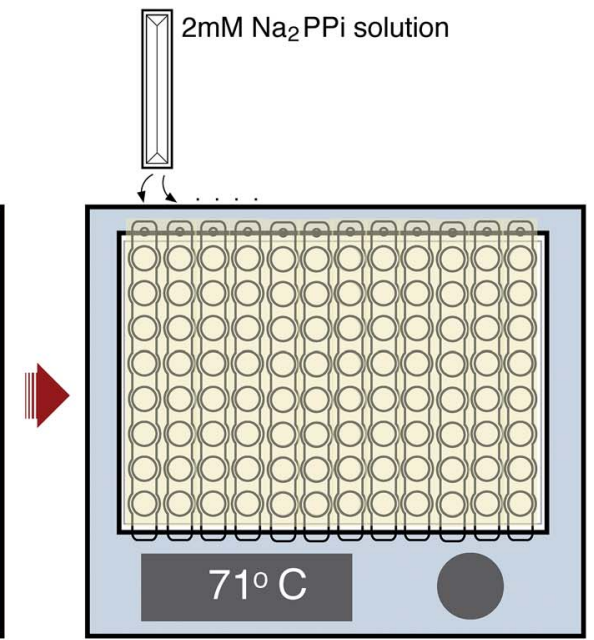

$2 \mathrm{mM} \mathrm{Na}{ }_{2} \mathrm{PPi}$ addition and further incubation for $5 \mathrm{~min}$.

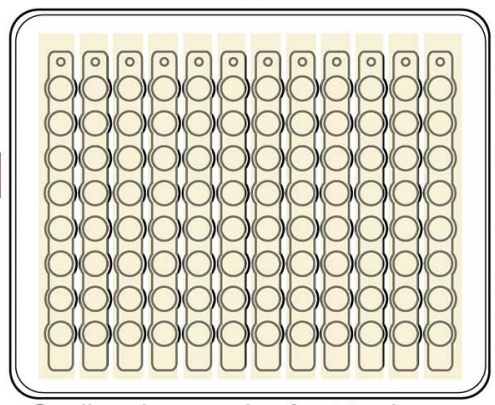

Cooling down on ice for $10 \mathrm{~min}$, then addition of Solution $A+B$.

Fig. 1 Step by step illustration of the assay.

vapour that had condensed on the sealing sheet, thus minimising the differences in the reaction volumes in each tube.

After enzyme inactivation, $60 \mu \mathrm{L}$ of solution A + B (see above) was added to the reaction mixture to determine the amount of phosphate produced according to the method of Baginski and coworkers. $^{34}$ The addition of solution A + B generates a dark blue colour that appears immediately and develops over a 10 minute time on the cooling apparatus $\left(0^{\circ} \mathrm{C}\right)$. Incubation at $0{ }^{\circ} \mathrm{C}$ prevents acid-catalysed hydrolysis compared to incubation at room temperature ${ }^{35}$ Solution $\mathrm{A}$ and $\mathrm{B}$ cannot be added individually to the reaction mixture because it produces colour inconsistency and lowers the intensity of the final product. ${ }^{36}$

Subsequent addition of $90 \mu \mathrm{L}$ of the arsenic-citrate solution to the reaction mixture at room temperature was used to stabilise the dark blue solution, which has absorption maxima at $709 \mathrm{~nm}$ and $860 \mathrm{~nm}$ (Fig. 2). Arsenite appears to enhance the colour formation while citrate complexes excess molybdate in the solution, ${ }^{34}$ thus inhibiting further colour development due to any phosphate liberated by non-enzymatic $\mathrm{PP}_{\mathrm{i}}$ cleavage..$^{35}$ For $\mathrm{P}_{\mathrm{i}}$ determination, we measured at $860 \mathrm{~nm}$ based on the observation of $\mathrm{He} \&$ Honeycut $^{37}$ that measurement at longer wavelengths increased the detection limit and sensitivity. We observed that, at $860 \mathrm{~nm}$, the blue colour developed within 30 minutes of incubation at room temperature and was stable for at least five hours (Fig. 3).

The molybdenum blue assay we use is sensitive to interference from $\geq 1 \mathrm{mM} \mathrm{MgCl}_{2}, \geq 5 \mathrm{mM}$ EDTA and $\geq 20 \%$ glycerol $^{38}$ and high concentrations of phosphoryl compounds (2-10 mM $\mathrm{PP}_{\mathrm{i}}$, ATP, $\beta$-glycerophosphate and $p$-nitrophenylphosphate).$^{35} \mathrm{As}$ the assay conditions that we employ do not require interfering concentrations of these reagents, the assay is well suited for our purposes.

\section{The activity of Thermotoga maritima mPPase}

To test the method, we determined the activity of TmPPase, a thermophilic mPPase from T. maritima and its inhibition by known inhibitors. We used this enzyme because it can be easily produced and purified, has good stability, high specific activity, and also has a conserved catalytic region with other mPPases including the parasite homologs. TmPPase expression and 


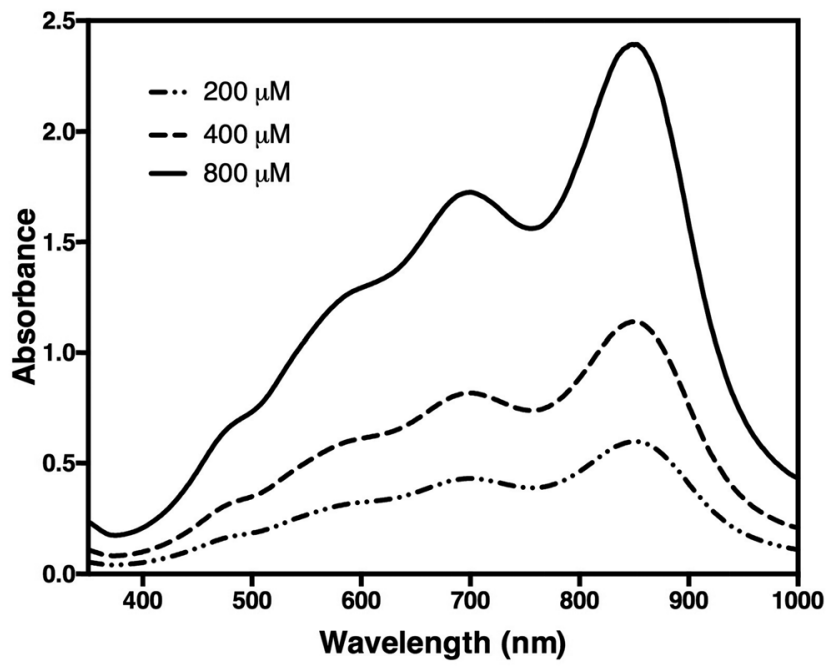

Fig. 2 Spectra of a sample containing 200, 400, and $800 \mu \mathrm{M}$ of orthophosphate $\left(\mathrm{P}_{\mathrm{i}}\right)$. Measurement was carried out in $10 \mathrm{~mm}$ cuvettes against control buffer. Two peaks were observed at $709 \mathrm{~nm}$ and $860 \mathrm{~nm}$.

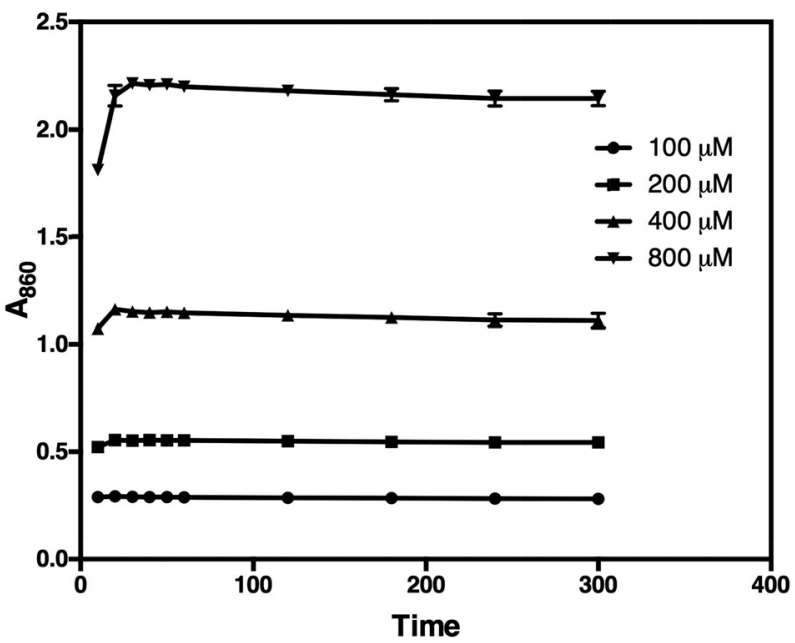

Fig. 3 The blue colour development of $100,200,400$, and $800 \mu \mathrm{M} \mathrm{P}$ (50 $\mu \mathrm{L}$ reaction mixture) and its stability over time at the wavelength of $860 \mathrm{~nm}$. The absorbance reaches a maximum after 30 minutes of incubation at room temperature.

purification have been previously described. ${ }^{30}$ Before use, the pure protein was reactivated with $4.52 \%$ DDM and $12 \mathrm{mg} \mathrm{mL}^{-1}$ soybean lecithin. Based on the calibration curve (Fig. 4), the lower and the upper limit of the assay were $10 \mu \mathrm{M}$ and $800 \mu \mathrm{M}$ of $\mathrm{P}_{\mathrm{i}}$, respectively. After 24 hours, the absorbance maxima of the calibration solutions decreased by $10 \%$, but were still linear over the range tested (data not shown). Based on this method, TmPPase has higher specific activity $\left(140.7 \pm 7.01 \mu \mathrm{mol} \mathrm{P}_{\mathrm{i}}\right.$ per $\mathrm{mg}$ per $\mathrm{min}$ ) compared to our previously reported values (20 $\mu \mathrm{mol} \mathrm{P}_{\mathrm{i}}$ per $\mathrm{mg}$ per min), which used $0.015 \%$ DDM and $0.12 \mathrm{mg} \mathrm{mL}^{-1}$ soybean lecithin for reactivation. ${ }^{30}$

In the initial testing, we tested reaction times from 1-10 minutes (Fig. 5). As the phosphate release as a function of

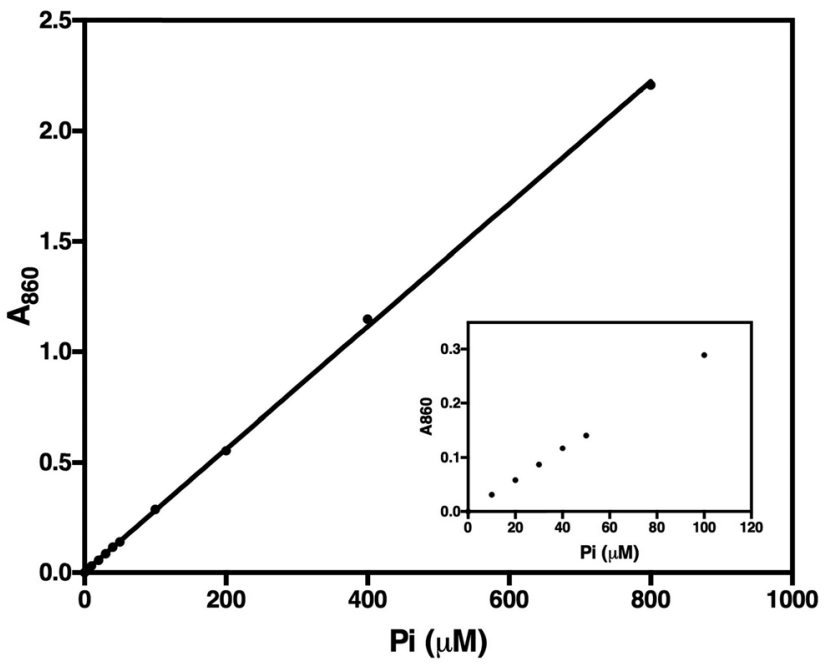

Fig. 4 Calibration curve of orthophosphate $\left(P_{\mathrm{i}}\right)$ determination in $50 \mu \mathrm{L}$ reaction mixture after 30 minutes incubation at room temperature. Inset shows the absorbance linearity of 0 to $100 \mu \mathrm{M} \mathrm{P}$. The line fit is linear over the concentration range tested $(y=0.0555 x+0.0059$; $\left.r^{2}=1.000\right)$.

time was linearly correlated in the tested time range, we chose 5 minutes as a suitable reaction time for high-throughput screening. This was because the absorbance of the phosphate released was in this case in the mid-range of the calibration standard (Fig. 4), which also makes the concentration of the phosphate suitable for the assay. To test the accuracy of this assay we carried out measurements on five different plates on three different days and calculated a $Z^{\prime}$-factor ${ }^{39}$ of 0.736 for the assay, which indicates that the 5 minute incubation is sufficient for reliable screening.

We tested two mPPase inhibitors, imidodiphosphate (IDP) and $\mathrm{Ca}^{2+}$, and one inhibitor, fluoride, of soluble PPases. Structures of TmPPase in complex with IDP ${ }^{40}$ and $\mathrm{Ca}^{2+}$ (ref. 31) has

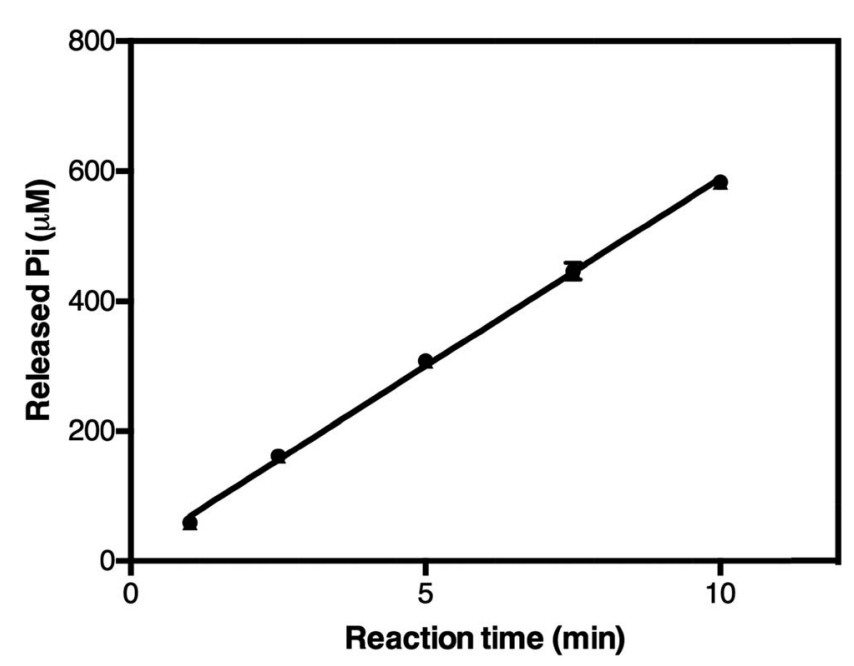

Fig. 5 The release of orthophosphate in TmPPase-containing $50 \mu \mathrm{L}$ reaction mixtures after different incubation times at $71^{\circ} \mathrm{C}$. The line fit is linear over the time range tested $\left(y=57.76 x+11.36 ; r^{2}=0.9972\right)$. 
A

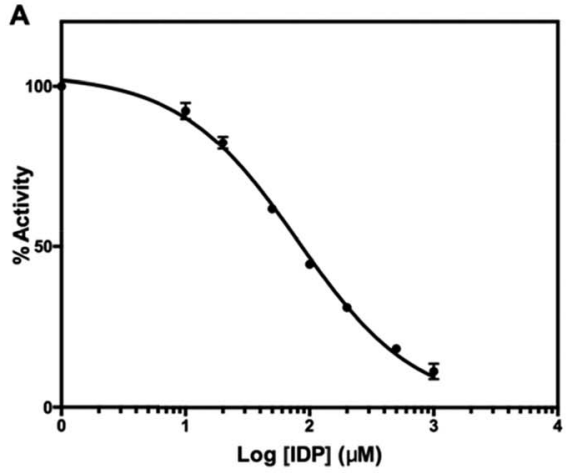

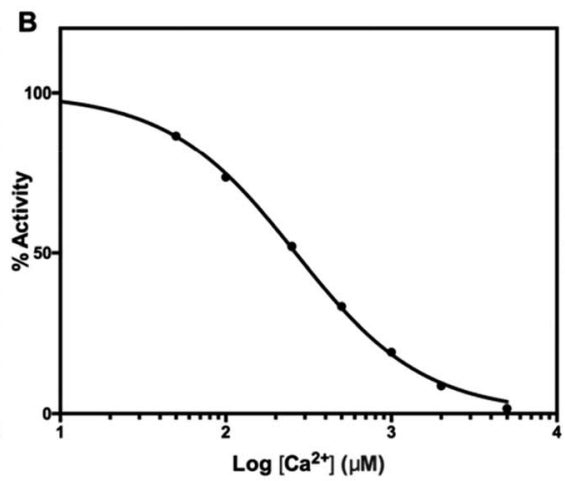

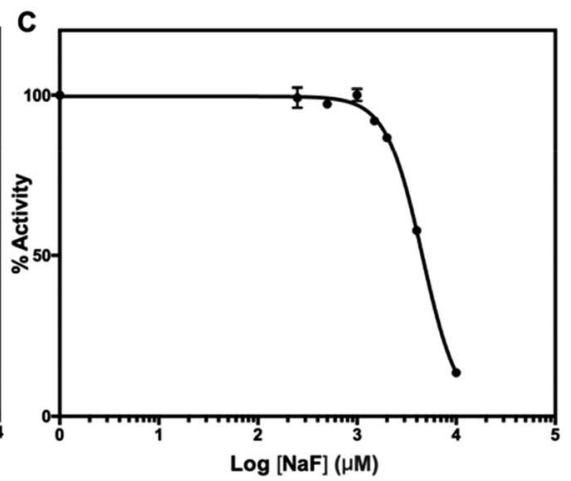

Fig. 6 Inhibition of TmPPase by (A) IDP, (B) $\mathrm{CaCl}_{2}$, and (C) NaF. IDP, $\mathrm{CaCl}_{2}$, and $\mathrm{NaF}$ inhibited TmPPase with the log IC 50 of $1.90 \pm 0.022$ (IC $50=$ $80.0 \mu \mathrm{M}), 2.42 \pm 0.009\left(\mathrm{IC}_{50}=264.0 \mu \mathrm{M}\right)$, and $3.66 \pm 0.008\left(\mathrm{IC}_{50}=4.6 \mathrm{mM}\right)$, respectively.

been solved. IDP binds to the hydrolytic centre of the enzyme, and $\mathrm{Ca}^{2+}$ to the conserved aspartic residues (D688, D692, and D669) in the hydrolytic centre. Both IDP and $\mathrm{CaCl}_{2}$ inhibited the
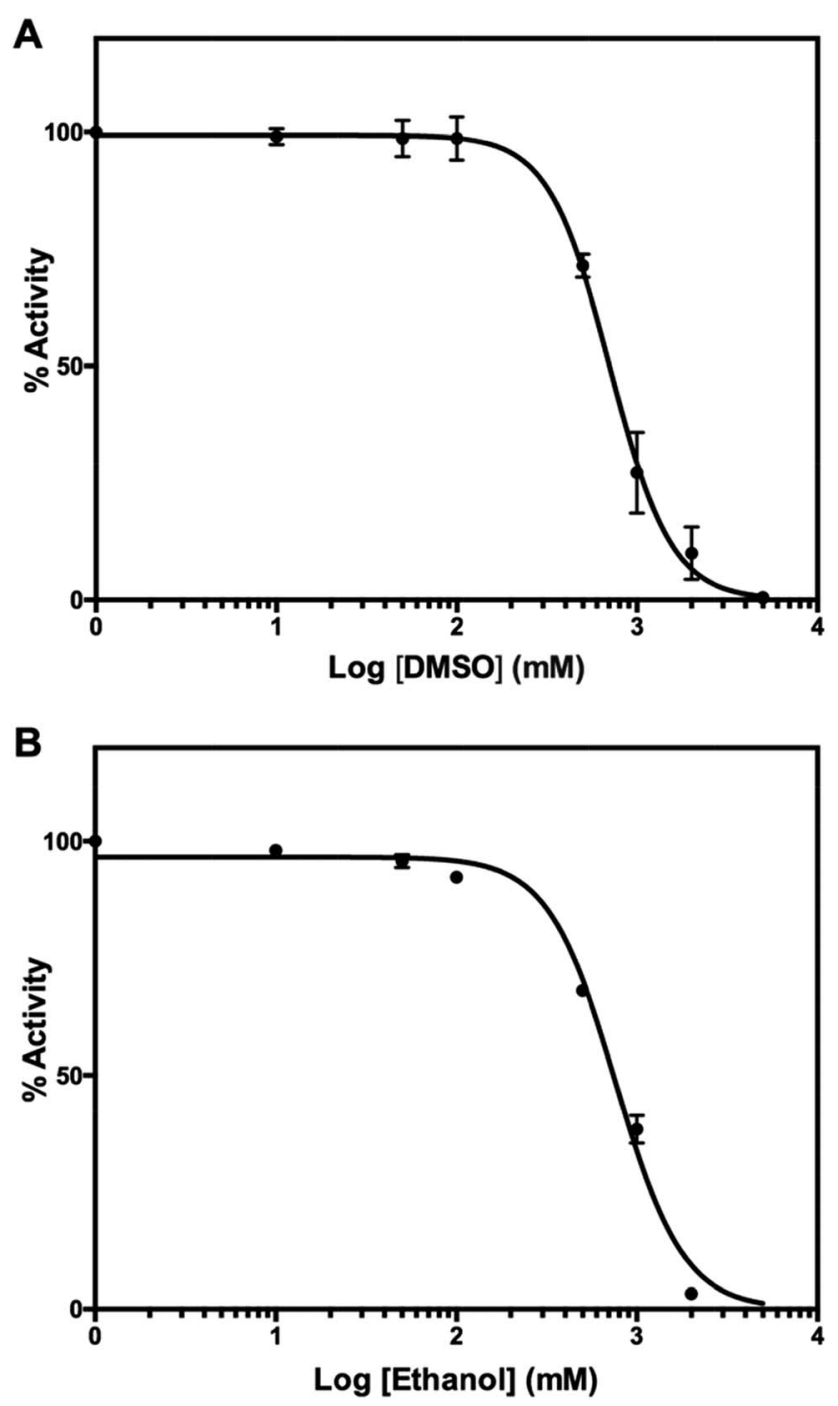

Fig. 7 Effect of organic solvent, (A) DMSO and (B) ethanol, on the activity of TmPPase. activity of TmPPase with $\log \mathrm{IC}_{50}$ of $1.90 \pm 0.02\left(\mathrm{IC}_{50}=80.0 \mu \mathrm{M}\right)$ for IDP and $2.42 \pm 0.009\left(\mathrm{IC}_{50}=264.0 \mu \mathrm{M}\right.$ ) for total Ca ${ }^{2+}$ (Fig. 6). Even though fluoride did not inhibit the TmPPase activity at low concentration, at higher concentration it inhibited with $\log \mathrm{IC}_{50}$ of $3.66 \pm 0.008\left(\mathrm{IC}_{50}=4.6 \mathrm{mM}\right)$ (Fig. 6). This is probably due the sequestering of $\mathrm{Mg}^{2+}$ ion by $\mathrm{F}^{-}$from the reaction mixture and enzyme active site to form $\mathrm{MgF}_{2}$. This result is similar with the fluoride inhibition of mPPase from $R$. rubrum and $V$. radiata with the $K_{i}$ values of 4.8 and $3.4 \mathrm{mM}$, respectively. ${ }^{41}$

For experimental screening of mPPase inhibitors, target compounds are usually dissolved in organic solvents such as DMSO or ethanol. To check whether either organic solvent inhibits TmPPase activity, we performed the same assay as before. DMSO and ethanol inhibited the TmPPase activity at very high concentration with $\log \mathrm{IC}_{50}$ of $2.85 \pm 0.014\left(\mathrm{IC}_{50}=709 \mathrm{mM}\right)$ and $2.88 \pm 0.015\left(\mathrm{IC}_{50}=766 \mathrm{mM}\right)$, respectively (Fig. 7). Even though both solvents have similar $\mathrm{IC}_{50}$, DMSO did not affect the TmPPase activity at $100 \mathrm{mM}$ concentration, while ethanol decreased the activity to about $92 \%$. Therefore, DMSO is a better solvent for target compounds when screening mPPase inhibitors.

\section{Conclusions}

In conclusion, we have shown that the molybdenum blue method can be applied for medium-throughput (96 well plate) assay of TmPPase activity at high temperature. The assay is a simple, cheap, and sensitive way to determine the amount of phosphate released from the reaction. The colour developed by this method is also stable for at least 12 hours, so there is no need to measure the absorbance at the same time as the assay is being performed. The method can be further miniaturised for a 384-well plate assay, especially for testing mesophilic mPPases, which have optimal activity at ambient temperature. In this case sealing during the reaction to prevent evaporation should not be necessary. We are currently using this method to screen libraries to find drug candidates against various parasitic diseases.

\section{Conflicts of interest}

All authors declare no conflict of interest in this paper. 


\section{Acknowledgements}

This work is supported by the grants from Erkon Säätiö and the BBSRC (BB/M021610/1) to Adrian Goldman and the Academy of Finland (No. 308105) to Keni Vidilaseris and (No. 299762) to Juho Kellosalo. The authors thank Violeta Manole for her technical help.

\section{References}

1 T. Kajander, J. Kellosalo and A. Goldman, FEBS Lett., 2013, 587, 1863-1869.

2 T. C. Chao, H. Huang, J. Y. Tsai, C. Y. Huang and Y. J. Sun, Proteins: Struct., Funct., Bioinf., 2006, 65, 670-680.

3 T. Salminen, J. Käpylä, P. Heikinheimo, J. Kankare, A. Goldman, J. Heinonen, A. A. Baykov, B. S. Cooperman and R. Lahti, Biochemistry, 1995, 34, 782-791.

4 V. R. Samygina, A. N. Popov, E. V. Rodina, N. N. Vorobyeva, V. S. Lamzin, K. M. Polyakov, S. A. Kurilova, T. I. Nazarova and S. M. Avaeva, J. Mol. Biol., 2001, 314, 633-645.

5 P. Heikinheimo, J. Lehtonen, A. Baykov, R. Lahti, B. S. Cooperman and A. Goldman, Structure, 1996, 4, 14911508.

6 M. C. Merckel, I. P. Fabrichniy, A. Salminen, N. Kalkkinen, A. A. Baykov, R. Lahti and A. Goldman, Structure, 2001, 9, 289-297.

7 A. Serrano, J. R. Pérez-Castiñeira, M. Baltscheffsky and H. Baltscheffsky, IUBMB Life, 2007, 59, 76-83.

8 M. Seufferheld, M. C. F. Vieira, F. A. Ruiz, C. O. Rodrigues, S. N. J. Moreno and R. Docampo, J. Biol. Chem., 2003, 278, 29971-29978.

9 J. Li, H. Yang, W. A. Peer, G. Richter, J. Blakeslee, A. Bandyopadhyay, B. Titapiwantakun, S. Undurraga, M. Khodakovskaya, E. L. Richards, B. Krizek, A. S. Murphy, S. Gilroy and R. Gaxiola, Science, 2005, 310, 121-125.

10 E. V. D'yakova, A. L. Rakitin, A. M. Kamionskaya, A. A. Baikov, R. Lahti, N. V. Ravin and K. G. Skryabin, Dokl. Biol. Sci., 2006, 409, 346-348.

11 F. Gao, Q. Gao, X. Duan, G. Yue, A. Yang and J. Zhang, J. Exp. Bot., 2006, 57, 3259-3270.

12 F. Brini, M. Hanin, I. Mezghani, G. A. Berkowitz and K. Masmoudi, J. Exp. Bot., 2007, 58, 301-308.

13 M. T. McIntosh, Y. M. Drozdowicz, K. Laroiya, P. A. Rea and A. B. Vaidya, Mol. Biochem. Parasitol., 2001, 114, 183-195.

14 R. Docampo, W. de Souza, K. Miranda, P. Rohloff and S. N. J. Moreno, Nat. Rev. Microbiol., 2005, 3, 251-261.

15 J. Liu, D. Pace, Z. Dou, T. P. King, D. Guidot, Z.-H. Li, V. B. Carruthers and S. N. J. Moreno, Mol. Microbiol., 2014, 93, 698-712.

16 N. R. Shah, K. Vidilaseris, H. Xhaard and A. Goldman, AIMS Biophys., 2016, 3, 171-194.

17 C. H. Fiske and Y. Subbarow, J. Biol. Chem., 1925, 66, 375400.
18 A. A. Baykov, O. A. Evtushenko and S. M. Avaeva, Anal. Biochem., 1988, 171, 266-270.

19 J. Deng, Q. Jiang, Y. Wang, L. Yang, P. Yu and L. Mao, Anal. Chem., 2013, 85, 9409-9415.

20 J. K. Heinonen and R. J. Lahti, Anal. Biochem., 1981, 113, 313-317.

21 B. Martin, C. J. Pallen, J. H. Wang and D. J. Graves, J. Biol. Chem., 1985, 260, 14932-14937.

22 D. H. Vance and A. W. Czarnik, J. Am. Chem. Soc., 1994, 116, 9397-9398.

23 K. Xu, Z. Chen, L. Zhou, O. Zheng, X. Wu, L. Guo, B. Qiu, Z. Lin and G. Chen, Anal. Chem., 2015, 87, 816-820.

24 M. Hill and B. Arrio, Anal. Biochem., 1997, 254, 249-253.

25 J. Eriksson, S. Karamohamed and P. Nyrén, Anal. Biochem., 2001, 293, 67-70.

26 R. H. Upson, R. P. Haugland, M. N. Malekzadeh and R. P. Haugland, Anal. Biochem., 1996, 243, 41-45.

27 H. P. Bloemers, M. L. Stephenson and P. C. Zamecnik, Anal. Biochem., 1970, 34, 66-70.

28 E. A. Nagul, I. D. McKelvie, P. Worsfold and S. D. Kolev, Anal. Chim. Acta, 2015, 890, 60-82.

29 G. A. Belogurov, A. M. Malinen, M. V. Turkina, U. Jalonen, K. Rytkönen, A. A. Baykov and R. Lahti, Biochemistry, 2005, 44, 2088-2096.

30 J. Kellosalo, T. Kajander, M. G. Palmgren, R. L. LopézMarqués and A. Goldman, Protein Expression Purif., 2011, 79, 25-34.

31 J. Kellosalo, T. Kajander, K. Kogan, K. Pokharel and A. Goldman, Science, 2012, 337, 473-476.

32 S. M. Lin, J. Y. Tsai, C. D. Hsiao, Y. T. Huang, C.-L. Chiu, M. H. Liu, J. Y. Tung, T. H. Liu, R. L. Pan and Y. J. Sun, Nature, 2012, 484, 399-403.

33 R. L. López-Marqués, J. R. Pérez-Castiñeira, M. J. BuchPedersen, S. Marco, J.-L. Rigaud, M. G. Palmgren and A. Serrano, Biochim. Biophys. Acta, Biomembr., 2005, 1716, 69-76.

34 E. S. Baginski, P. P. Foa and B. Zak, Clin. Chim. Acta, 1967, 15, 155-158.

35 M. Hørder, Anal. Biochem., 1972, 49, 37-47.

36 M. J. Black and M. E. Jones, Anal. Biochem., 1983, 135, 233238.

37 Z. He and C. W. Honeycutt, Commun. Soil Sci. Plant Anal., 2005, 36, 1373-1383.

38 S. Chifflet, A. Torriglia, R. Chiesa and S. Tolosa, Anal. Biochem., 1988, 168, 1-4.

39 J. H. Zhang, T. D. Y. Chung and K. R. Oldenburg, J. Biomol. Screening, 1999, 4, 67-73.

40 K. M. Li, C. Wilkinson, J. Kellosalo, J. Y. Tsai, T. Kajander, L. J. C. Jeuken, Y. J. Sun and A. Goldman, Nat. Commun., 2016, 7, 13596.

41 A. A. Baykov, E. B. Dubnova, N. P. Bakuleva, O. A. Evtushenko, R. G. Zhen and P. A. Rea, FEBS Lett., 1993, 327, 199-202. 